Reprod. Nutr. Dévelop., 1988, 28 (6 B), 1629-1648.

\title{
Embryo-uterine interactions during early stages of pregnancy in domestic mammals
}

\author{
M. GUILLOMOT, Pierrette REINAUD, G. CHARPIGNY, J. MARTAL
}

Unité d'Endocrinologie de l'Embryon,

I.N.R.A., 78350 Jouy-en-Josas, France.

Summary. The first part of this paper presents data concerning our knowledge of uterine proteins during early pregnancy in domestic mammals; the second part gives results of in vitro biochemical studies on embryo-uterine interactions in the ewe.

We have developed an in vitro technique of the co-culture of ovine uterine epithelial cells with the blastocyst or its secretory proteins. The effects of a specific trophoblastic protein (oTPB), involved in the maintenance of the corpus luteum, have been particularly studied by this system. The modifications of endometrial protein synthesis have been measured by incorporation of radiolabelled amino acids and analysed by electrophoresis (SDS-PAGE or bidimensional). The results show that the presence of the blastocyst, or of its total secretory proteins or oTPB alone, decreased overall protein synthesis by the endometrial cells. The nature of the secreted proteins was apparently not affected by the blastocyst, but the addition of oTPB alone increased the production of 3 polypeptides ( $\mathrm{MW}=150 \cdot 10^{3} ; 74 \cdot 10^{3} ; 50 \cdot 10^{3}$ and $\mathrm{pl}=7-8.2 ; 5.4-5.2 ; 6.4$, respectively) and decreased the synthesis of 2 others $\left(\mathrm{MW}=57 \cdot 10^{3} ; 35 \cdot 10^{3}\right.$ and $\mathrm{pl}=7-6.7 ; 5.3$, respectively).

We also studied the effects of co-culture with uterine cells on blastocyst DNA and protein synthesis. In no cases we obtained stimulation of blastocyst development during the co-culture period, and DNA or protein synthesis decreased in the presence of uterine cells.

In conclusion, the presence of specific uterine proteins has been established in some domestic mammals (pig, rabbit) but not in all of them. Although local modifications of uterine protein synthesis are induced by the embryo or its secretory products, the nature and the role of the proteins which are affected need to be determined by further studies.

\section{Introduction.}

The pre-implantation period of gestation is characterized by interactions between the conceptus (the embryo and its associated membranes) and the maternal endometrium, which are necessary to the maintenance of the corpus luteum and to endometrial secretion of an environment favourable to embryonic development. In domestic mammals (cows, sheep, pigs, horses) the attachment of the conceptus to the uterine epithelium occurs late after its entry into the uterine cavity (table 1 ). This implies that in these species, the development of embryo, during the period of its «free-life», is closely dependent on the uterine 
environment. Embryo transfer experiments in different species indicate that a close synchrony must be obtained between the developmental stage of the embryo and the hormonal status of the recipient endometrium (Moore and Shelton, 1964 ; Rowson and Moor, 1966 ; Rowson et al., 1972 ; Wilmut et al., 1985 ; Pope and First, 1985). Another example, emphasizing the role of uterine environment on embryonic development, is given by species which exhibit natural (roe deer, mink) or induced (rat, mouse) delayed implantation. During this process, the blastocyst is maintained dormant (diapause) for a period which may last several months. The activation and subsequent implantation of the blastocyst are associated with a resumption of the secretory activity of the endometrium under the influence of maternal hormones (Aitken, 1981; Surani, 1975).

TABLE 1

Comparative data on reproductive events in domestic mammals.

\begin{tabular}{lccccc}
\hline Species & $\begin{array}{c}\text { Entry into } \\
\text { the uterine } \\
\text { cavity } \\
\text { (Day p.c.) }\end{array}$ & Hatching & $\begin{array}{c}\text { Length } \\
\text { Implantation } \\
\text { (Day p.c.) }\end{array}$ & $\begin{array}{c}\text { Length } \\
\text { of oestrus } \\
\text { cycle } \\
\text { (Days) }\end{array}$ & $\begin{array}{c}\text { of gestation } \\
\text { (Days) }\end{array}$ \\
\hline Sheep & 5 & $7-9$ & $15-20$ & 17 & $145-150$ \\
Cow & 5 & $9-10$ & $19-25$ & 22 & 280 \\
Pig & $2-3$ & $5-6$ & 14 & 21 & 114 \\
Horse & 6 & $*$ & $25-30$ & $19-22$ & 330 \\
\hline
\end{tabular}

* In this species there is no hatching, the zona pellucida beeing progressively replaced by a capsule which surrounds the conceptus until implantation.

Although many studies have documented the fact that uterine environment plays a key-role in embryonic development, only a few uterine secretory proteins have been isolated and characterized. In the first part of this paper we review some data concerning our knowledge of endometrial proteins in domestic mammals (see also Bazer et al., 1981). In the second part, we report studies on the secretory activity of the endometrium and utero-embryonic interactions in vitro during the early stages of pregnancy, mainly in sheep, with references to work in progress in our laboratory.

\section{Uterine proteins.}

The "preimplantation" endometrium is under the influence of ovarian hormones, mainly progesterone. Therefore, studies on the secretory activity of the endometrium during the early stages of pregnancy have led to the characterization of progesterone-induced proteins (table 2). The rabbit and the pig have been particularly well investigated.

Rabbits. - A well-known uterine protein in this species is uteroglobin (Beier, 1976) or blastokinin (Daniel, 1976). This protein, secreted by the rabbit endometrium, is induced by progesterone (Beier, 1976 ; Beato, 1977). However, 


\section{TABLE 2}

Progesterone-induced uterine proteins characterized during early pregnancy.

\begin{tabular}{|c|c|c|c|c|c|}
\hline Species & Protein & M.W. $\times 10^{-3}$ & $\mathrm{pl}$ & $\begin{array}{l}\text { Functions or } \\
\text { properties }\end{array}$ & Authors \\
\hline Rabbit & Uteroglobin & 14 & 5.4 & binds progesterone & $\begin{array}{c}\text { Daniel, } 1976 \\
\text { Beier, } 1976 \\
\text { Beato, } 1977\end{array}$ \\
\hline \multirow[t]{3}{*}{ Pig } & $\begin{array}{c}\text { Uteroferrin } \\
\text { Plasmin inhibitor }\end{array}$ & $\begin{array}{c}30-40 \\
14\end{array}$ & $\begin{array}{l}\text { basic } \\
\text { basic }\end{array}$ & $\begin{array}{c}\text { iron carrier } \\
\text { protease inhibitor }\end{array}$ & $\begin{array}{c}\text { Chen et al., } 1975 \\
\text { Mullins et al., } 1980\end{array}$ \\
\hline & Lysozyme & 14 & basic & antibacterial & $\begin{array}{c}\text { Roberts R.M. et al., } \\
1976\end{array}$ \\
\hline & $\begin{array}{c}\text { Retinol-binding } \\
\text { proteins }\end{array}$ & $17-20$ & $6.3-6.1$ & vitamin-A carrier & Adams et al., 1981 \\
\hline Horse & Uteroferrin-like & $30-40$ & basic & acid phosphatase & Zavy et al., 1982 \\
\hline
\end{tabular}

it is not a uterine specific protein since it has been found in other organs (lungs : Bullock, 1977; vas deferens: Noske and Feigelson, 1976). However, in these extra-uterine sites, uteroglobin is not progesterone dependent (Savouret et al., 1980). Its amino acid sequence (Ponstingl et al.. 1978 ; Popp et al., 1978) and crystalline structure (Mornon et al., 1980) have been determined; the gene has been cloned (Chandra et al., 1980). Uteroglobin binds progesterone (Beato, 1977; Fridlansky and Milgrom, 1976) and passes through the blastocyst coverings (Kirchner, 1972). The significance of its presence in uterine secretion remains obscure. Krishnan and Daniel (1967) coined the name "blastokinin » because of its effects on blastocyst development in vitro, but these results were not confirmed by other studies (Beier, 1976). It has been suggested that its ability to bind progesterone would protect the embryo from excessive concentrations of the free steroid. However, the role of uteroglobin on embryonic development has not been demonstrated yet. Recent data indicate that uteroglobin may have some immunomodulatory properties by masking surface antigens of the embryo and that it may be also a potent anti-inflammatory agent via the inhibition of phospholipase A2 activity (Miele et al., 1987). Further studies are needed to confirm these hypotheses.

Non-uteroglobin proteins have been also described in the rabbit under progesterone stimulation. These include endometrial proteases which are probably involved in the digestion of blastocyst coverings (Kirchner, 1980) and high molecular weight proteins ( $M W \geqslant 100 \mathrm{KD}$ ) (Dunbar and Daniel, 1979). No particular function has been attributed to the latter uterine components.

Pigs. - In the pig the progesterone-induced protein, uteroferrin, has been the subject of numerous studies (see review by Roberts and Bazer, 1988). This protein is a major component of uterine flushings from the sow during the luteal phase of the oestrous cycle and during pregnancy with maximum synthesis between Days 35 and 75 (around $15 \%$ of the total protein content). Uteroferrin 
has a distinct purple colour due to the presence of tyrosine residues. One of these iron atoms is more easily reduced than the other, and treatment of the protein with a reducing agent results in a $\mathrm{Fe}^{++}-\mathrm{Fe}^{+++}$ion pair (Roberts and Bazer, 1988). It is a glycoprotein ( $\mathrm{MW}=35,000$; basic $\mathrm{pl}$ ) with a known structure ; cDNA clones corresponding to uteroferrin-mRNA have been produced (Simmen et al., 1987). The reduced form of uteroferrin is a potent acid phosphatase (Schlosnagle et al., 1974, 1976). The function of this protein is to transport iron from the endometrium to the conceptus (Chen et al., 1975; Roberts et al., 1986). An uteroferrin-like protein has been detected in flushings from the mare (Zavy et al., 1982) but not in other domestic mammals.

A second group of proteins, retino/-binding proteins ( $\mathrm{MW}=17-20,000 ; \mathrm{pl}$ $=6.3-6.1$ ) which are involved in nutrient transport has been described in pig uterine flushings. These proteins are present in uterine secretions from sows in the luteal phase of the oestrous cycle and from ovariectomized sows treated with progesterone (Adams et al., 1981). Retinol-binding proteins are probably involved in the transport of vitamin $A$ to the foetus. However, the endometrial origin of these proteins is questionable since a retinol-binding protein has been shown to be present in the serum (Bazer et al., 1981).

Other types of progesterone-induced proteins have been observed in pig uterine secretions. A class of protease inhibitors, plasmin inhibitors, have been described in uterine flushings during the luteal phase of the oestrous cycle. This protein inhibits plasminogen activity of blastocyst origin (Mullins et al., 1980; Fazleabas et al., 1982). In the pig, there is no invasive implantation, and it has been suggested that plasmin inhibitor could prevent the potential erosive activity of the trophoblast in this species (Fazleabas et al., 1983). However, it must be pointed out that in species exhibiting almost the same type of implantation (sheep, cow and horse), there is no evidence for the secretion of a plasmin inhibitor by the endometrium. Another function has been proposed such as the prevention of lysis of some other uterine proteins by embryonic proteases (Fazleabas et al., 1982).

Hydrolytic enzymes such as lysozyme are also present in the uterine secretions of progesterone-treated sows (Roberts R. M. et al., 1976); this enzyme is supposed to be an antibacterial agent.

Ewes and cows. - In these two species, none of the proteins described above have been reported. Most studies have been impaired by the low protein content in uterine secretions during the early stage of pregnancy or during the luteal phase of the oestrous cycle (20 g/l; Wales, 1973). Moreover, these proteins are mainly of serum origin (Roberts and Parker, 1974). However, specific uterine proteins have been described in cows (Roberts and Parker, 1974 ; Laster, 1977 ; Dixon and Gibbons, 1979) and in sheep (Roberts G. P. et al., 1976; Staples et al., 1978). Up to now, none of these proteins have been isolated and purified. Segerson (1988) reported that immunosuppressive factors are present in the uterine secretions of pregnant ewes. Since these results have been founded on the analysis of uterine flushings, the uterine specificity of these proteins is questionable. It is not always possible to distinguish between true secretory 
proteins (i.e. secreted by the uterine glands or the epithelium) and tissue proteins and/or proteins of different origin (serum or embryo). In sheep, Ménézo (1981) reported that different profiles of protein secretion were observed according to the techniques of uterine fluid collection (flushing vs cannulation). In the mouse, it has been demonstrated that during the flushing procedure large areas of endometrial epithelium are damaged, thus non-secretory proteins could contaminate uterine luminal content (Martin, 1984 ; Milligan and Martin, 1984). To overcome the problem of non-uterine specificity and also that of the small amounts of products available, different authors have undertaken in vitro studies of the secretory activity of the endometrium during the early stages of pregnancy. We present here the results obtained in sheep and cows.

\section{In vitro studies of embryo-uterine interactions in ruminants.}

The first studies tried to demonstrate pregnancy-related changes in the secretory activity of the endometrium. In sheep, data from the culture of endometrial explants are inconsistent. Findlay et al. (1981) have compared the rate of ${ }^{3} \mathrm{H}$-leucine incorporation in Day $11-15$ pregnant or non-pregnant endometrium and observed a significant increase in protein synthesis by the pregnant endometrium on Day 15. However, in a similar study, these results were not confirmed (Findlay et al., 1982). In the same way there were no differences in the secretory activity of the endometrium between pregnant or non-pregnant endometrial explants (Eyestone and French, 1981). These discrepancies account for the difficulties in showing any pregnancy-related change of protein synthesis by the ovine endometrium using these methods. In the cow, similar studies failed to demonstrate major changes in the protein released by endometrial tissue culture from pregnant or non-pregnant animals (Bartol et al., 1985). Data concerning the pig suggest that the embryo could act locally on the endometrium and affect protein synthesis. Endometrial explants from the unilaterally gravid horn release more proteins than explants from the non-gravid horn, but the nature of the polypeptides secreted by the endometrium is not different (Basha et al., 1980). However, in the cow, the co-culture of trophoblastic tissues with endometrial explants did not affect protein synthesis by the endometrium (Wathes, 1980). These results suggest that under the same hormonal influence (mainly progesterone) the endometrium of these species secretes the same proteins. However, some subtle changes in the nature of protein may have been missed. Most of these studies were founded on the analysis of secretions using whole endometrial tissue, including many different cell populations. Therefore, discrete changes in the nature of the secretory proteins could have been masked by the overall tissue secretion: According to Findlay et al. (1981) during short incubation $(4 \mathrm{~h})$, the secreted protein account for less than $1 \%$ of total protein synthesis.

For these reasons, the culture of isolated cells from the endometrium had to be developed. These methods allowed analysis of isolated populations of cells from the endometrium and the direct effects of the embryo (or its secretory products) on these cells. Our preliminary studies have shown that ovine 
trophoblastic tissue affects the protein synthesis of endometrial cells. Nine of the secreted proteins were increased and 5 were decreased (Guillomot et al., 1987). The trophoblastic factors responsible for such changes were not characterized, but it was shown that a protein (OTP1: ovine trophoblastic protein 1), in sheep, which is secreted by the pre-implantation conceptus, stimulated the synthesis of 6 polypeptides by endometrial explants (Godkin et al., 1984). The analogy between oTP1 and the antiluteolytic factor, trophoblastin (or oTPB) (Martal et al., 1979), has been established (Martal et al., 1988).
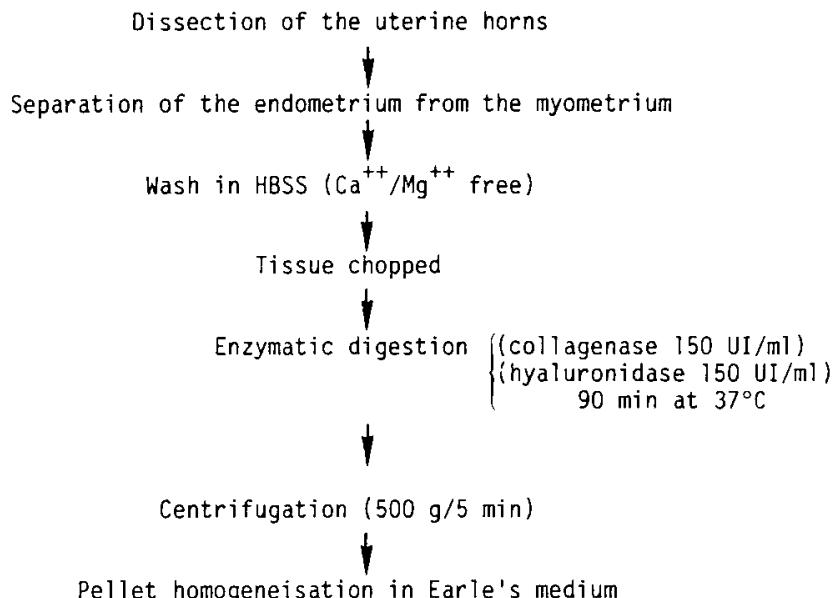

Filtration on sterile gauze

(retains large debris of tissues)

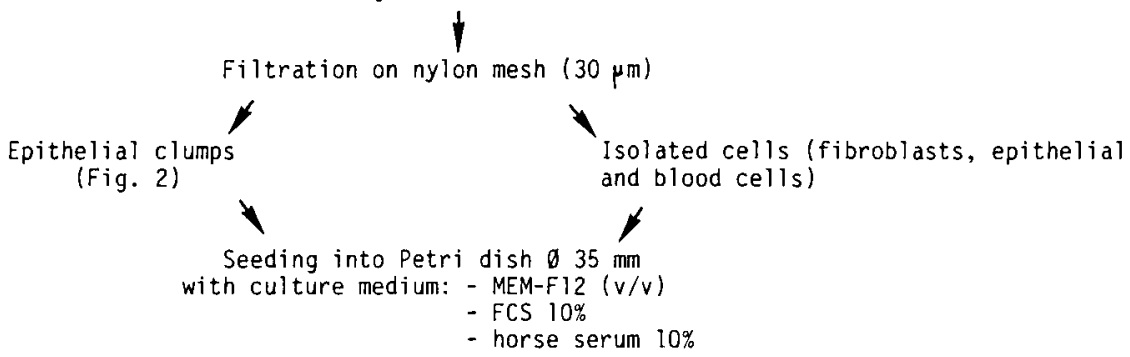

FIG. 1. - Experimental protocol for endometrial cell culture.

To investigate more precisely the embryo-induced changes of endometrial protein synthesis, we developed a method to culture epithelial and stromal cells separately. We analysed protein synthesis by uterine cells under different treatments : co-culture with blastocyst and incubation with a purified preparation of trophoblastin (oTPB). The cells were obtained according to the method 
described in figure 1. By these procedures, we collected clumps of epithelial cells (fig. 2) which were separated from the isolated stromal cells by filtration on a nylon mesh. In our culture conditions, the cells became confluent 3-4 days after seeding and were used for experiments at this stage. The epithelial nature of the cells was verified by immunocytochemical detection of cytokeratins (fig. 3 ) and by scanning electron microscope observations (fig. 4).

Effect of the blastocyst on uterine epithelial cells. - We have studied co-cultures of Day 11-12 blastocysts and endometrial cells from Day 11-12 pregnant or cyclic animals. At the end of co-culture $(24 \mathrm{~h}),{ }^{35} \mathrm{~S}$-methionine $\left({ }^{35} \mathrm{~S}\right.$-Met) was added to the culture medium and the cells were incubated for $24 \mathrm{~h}$. Quantitative analysis of the protein synthesis showed that the presence of the blastocyst had a slightly inhibitory effect on the incorporation of ${ }^{35} \mathrm{~S}-\mathrm{Met}$ by the uterine cells (fig. 5). But this effect was not statistically significant. Electrophoretic analysis of the secreted proteins from treated and control cells revealed no major changes in the nature of the endometrial proteins (fig. 6). These differences with our previous findings could result from the different origins of the embryonic factors involved. In the present experiment, we used Day 11-12 blastocysts instead of trophoblastic tissue from Day 17 conceptus. The amount and/or the nature of the secretory products from the whole blastocyst could be different than those from pieces of trophoblast from older embryos.

Effect of oTPB on uterine epithelial cells. - The addition of oTPB $(5 \mu \mathrm{g})$ to the culture medium of epithelial cells, or of mixed populations of cells, decreased the overall release of proteins in 4 out of 6 experiments. This effect was mimicked by addition of total proteins $(30 \mu \mathrm{g})$ extracted from the culture media of Day 15 conceptuses (figs. 7, 8). In similar experiments, Salamonsen et al. (1986) have reported that addition of blastocyst culture media (protein content : $3-10 \mu \mathrm{g}$ ) stimulated protein synthesis by uterine cells, but the difference with the control treatment was not significant. Moreover, at a higher concentration (over $30 \mu \mathrm{g}$ ) blastocyst proteins decreased protein synthesis by uterine cells. Godkin et al. (1984) have observed that oTP1 increased protein synthesis by endometrial explants. However, the studies of Vallet et al. (1987) in the same experimental conditions have not confirmed these quantitative data and the authors did not observe significant differences between oTP1-treated endometrial tissues and control ones. Whatever the experiments (explants or cell cultures), these authors agreed that total protein from the blastocyst or oTP1 affected the nature of the proteins secreted by the endometrium. In our experimental conditions, purified OTPB increased the protein synthesis of 3 polypeptides $\left(\mathrm{MW}=150 \cdot 10^{3}\right.$; $74 \cdot 10^{3} ; 50 \cdot 10^{3}$ and $\mathrm{pl}=7.2-7 ; 5.4-5.2 ; 6.4$, respectively) and decreased the epithelial cell production of 2 others $\left(\mathrm{MW}=57 \cdot 10^{3} ; 35 \cdot 10^{3}\right.$ and $\mathrm{pl}=7-6.7$; 5.3, respectively) (fig. 9). The increase of protein No. 2 was apparently more evident when OTPB was added to a mixed culture (epithelial cells plus fibroblasts) (fig. 10). This protein has the same physico-chemical characteristics as one of the polypeptides affected by oTP1 (Godkin et al., 1984 ; Vallet et al., 1987 ) and by blastocyst (Salamonsen et al., 1986). The interest in oTPB (or oTP1) studies has been renewed because this embryonic protein is also an 

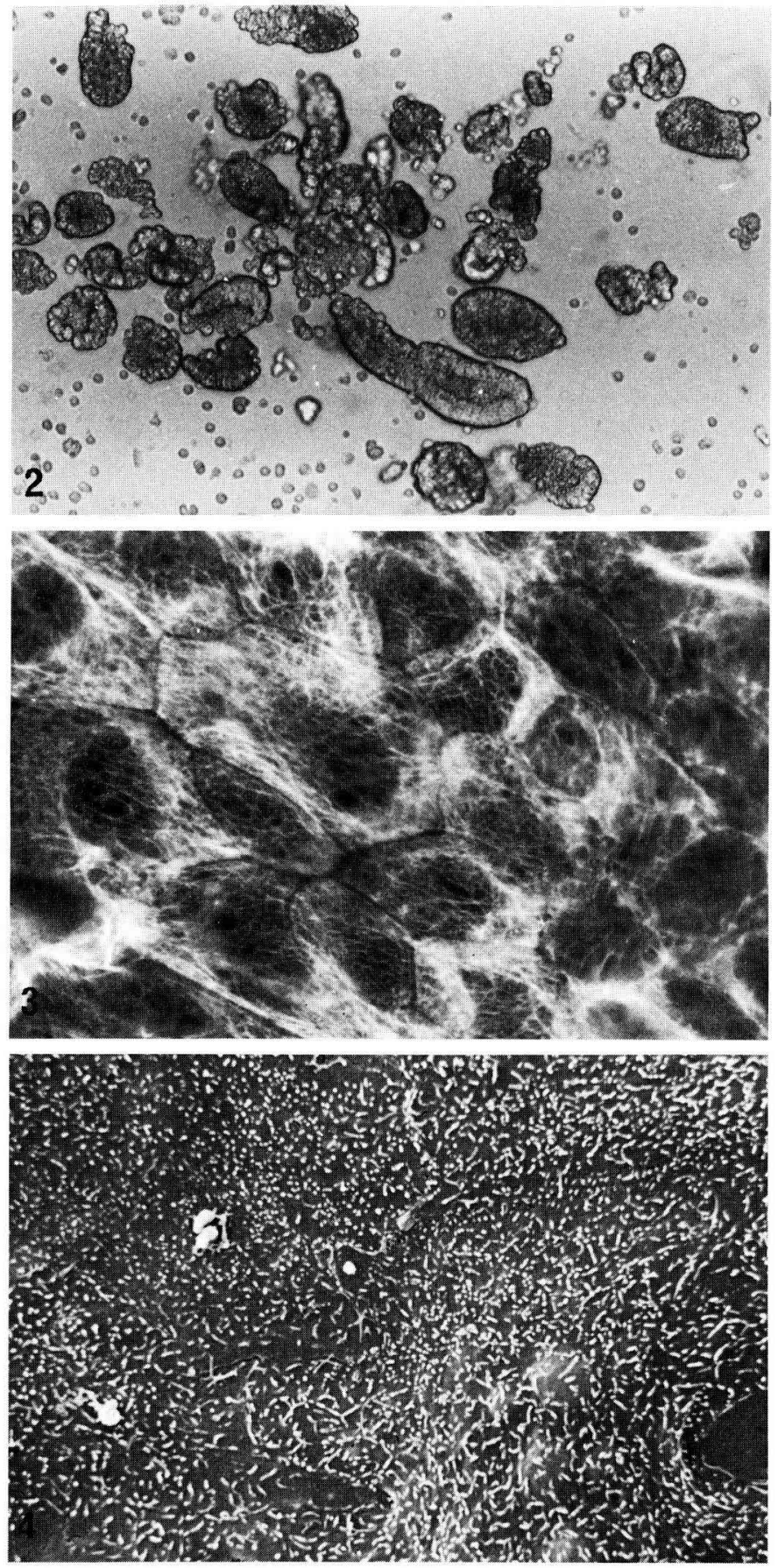


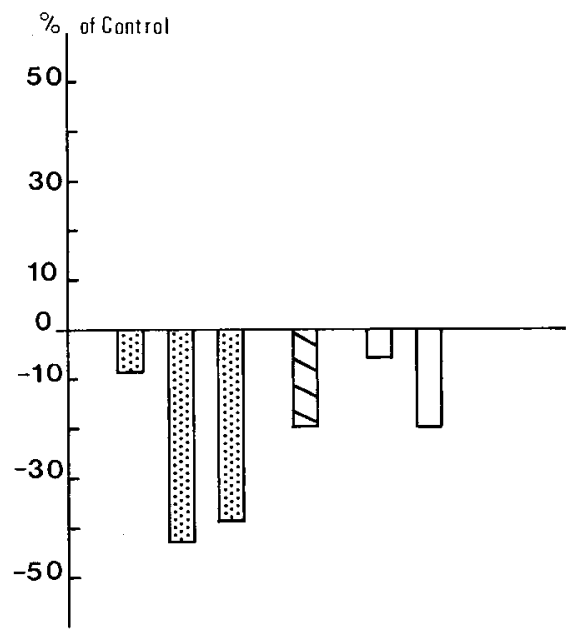

FIG. 5. - Effect of coculture with blastocyst on incorporation of ${ }^{35}$ S-met into proteins secreted by epithelial endometrial cells from D11 (dotted bars), D12 (hatched bar) pregnant and nonpregnant ewes at 012 of the oestrous cycle (open bars). Values are expressed as a percentage of control culture without added blastocyst.

interferon-like molecule (Imakawa et al., 1987 ; Stewart et al., 1987 ; Charpigny et al., 1988). Moreover, recent data have demonstrated that human interferon $\alpha^{2}$ can mimic the effect of oTP1 on protein synthesis and decrease prostaglandin secretion by ovine uterine cells (Salamonsen et al., 1988).

The precise function of the proteins affected by OTPB and/or proteins from the blastocyst is still unknow and must be further studied. Only some speculative hypotheses can be drawn. OTPB could act on the synthesis of some prostaglandin inhibitor. Such a factor has been detected in the endometrium of pregnant cows (Basu and Kindahl, 1987) and has been named "EPSI " (endometrial prostaglandin inhibitor synthetase) (Gross et al,, 1988). Evidence for EPSI-like factors in other species has not been demonstrated yet. One can also postulate that proteins of conceptus origin affect endometrial proteins which, in turn, control embryonic development.

Effect of co-culture of uterine cells on blastocyst development. - In various species, the culture of embryos on monolayer cells from the genital tract has been shown to sustain embryonic development in vitro (Gandolfi and Moor, 1987; Fukui and Ono, 1988 ; Marquant-Le Guienne et al., 1988). However, this effect is not specific since co-culture on non-endometrial (or oviductal) cell monolayers provided a favourable environment for embryonic development (Kuzan and

FIG. 2. - Epithelial clumps before seeding. $\times 200$.

FIG. 3. - Immunocytochemical characterization of cytokeratine of ovine epithelial cel/s in culture. $\times$ 900.

FIG. 4. - Scanning electron micrograph of ovine epithelial cells in culture. $\times 2,900$.

Reproduction, Nutrition, Développement, $n^{\circ} 6 \mathrm{~B} / 88-8$ 

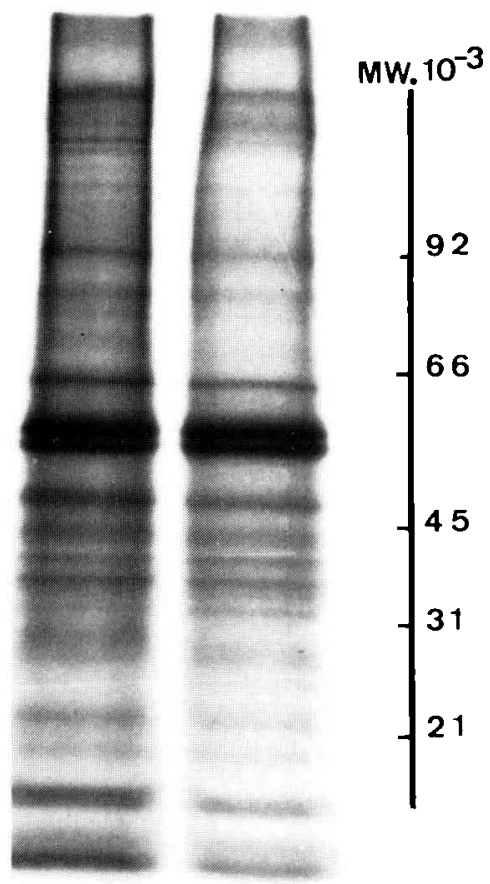

a b
FIG. 6. - Autoradiograph of SDS-PAGE profiles of proteins secreted by uterine epithelial cells from Day 12 non pregnant ewe cultured with Day 12 blastocyst (a) or without added blastocyst (b). No major modification is observed between the two profiles.

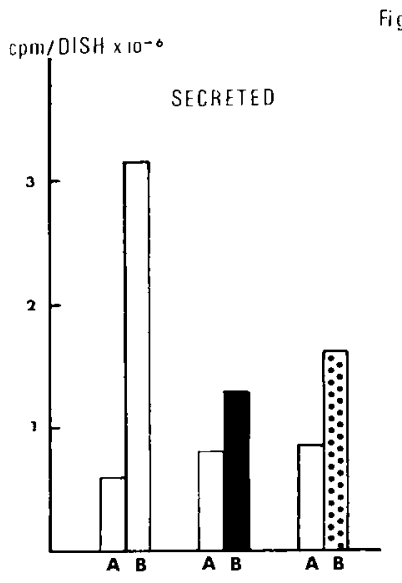

Fig. 7

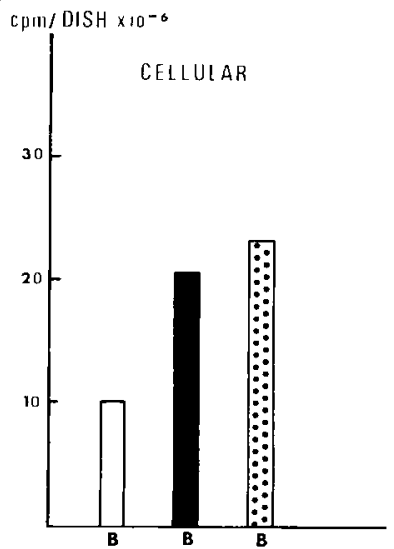

FIG. 7. - Incorporation of ${ }^{35} \mathrm{~S}$-met into secreted and cellular proteins by uterine epithelial ce//s incubated with oTPB ( $5 \mu \mathrm{g} / \mathrm{dish}$ ) (solid bars) or total secretory proteins from D 15 conceptus

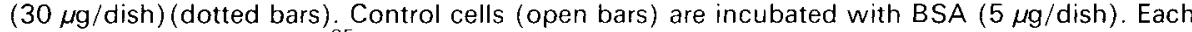
sample was cultured with ${ }^{35} \mathrm{~S}$-met $24 \mathrm{~h}$ before any treatment (A) and $24 \mathrm{~h}$ during treatment (B). Values represent a mean of duplicate culture dishes (cells from Day 13 cyclic ewe). 


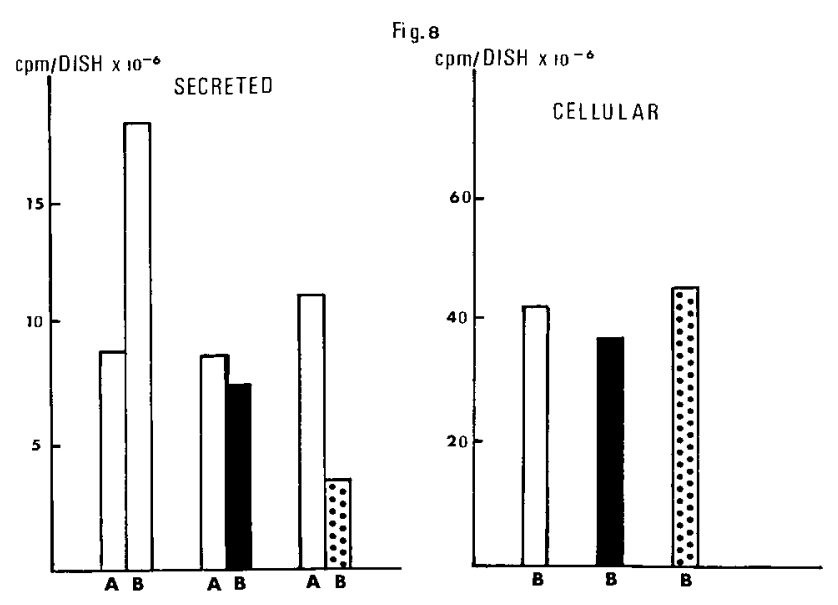

FIG. 8. - Same experiment as in figure 7. Culture of a mixed population of fibroblast and epithelial cells.

Wright, 1982 ; Allen and Wright, 1984). Most of these studies concerned early stage embryos (from the one-cell to the blastocyst stage). In older embryos the effect of uterine secretion in vitro has not been clearly established. In the pig, co-culture of trophoblast tissue with endometrial explants induced an increase in protein synthesis by the trophoblast, but the effect was only noticeable when the levels of the conceptus proteins were low before co-culture (Rice et al., 1981). In similar experiments, Wathes (1980) has not reported any difference in the rate of protein synthesis between co-cultured bovine trophoblast and control tissue. In the same way, culture of Day 11 bovine blastocysts with conditioned media from endometrial explant cultures had no effect on embryonic protein synthesis (Eyestone and French, 1981).

In our experimental conditions, we observed that co-culture of Day 11-12 blastocysts on ovine uterine cells had rather an inhibitory effect on DNA and protein synthesis by the embryos (figs. 11,12). These results raise questions since uterine secretions are assumed to nourish the developing embryo. Previous studies in rodents have described an inhibitory effect of uterine factors from delayed implantation secretions on blastocyst development in vitro (Weitlauf, 1976, 1978 ; Psychoyos and Casimiri, 1981). In the pig. Flint (1981) has reported the presence of both activator and inhibitor factors of DNA synthesis by trophoblast cultivated in the presence of uterine flushings. In this experiment, this effect was only apparent when uterine flushings were stored for a long time before use. When uterine extracts were used shortly after collection, they had an activating effect. The inhibitory factors found in rodents and in the pig have similarities. They are heat stable, dialysable products from the progesteronedominated uterus. In our experiment, the inhibitory effect on protein synthesis by the blastocyst was maintained after dialysis. The significance of the presence of 

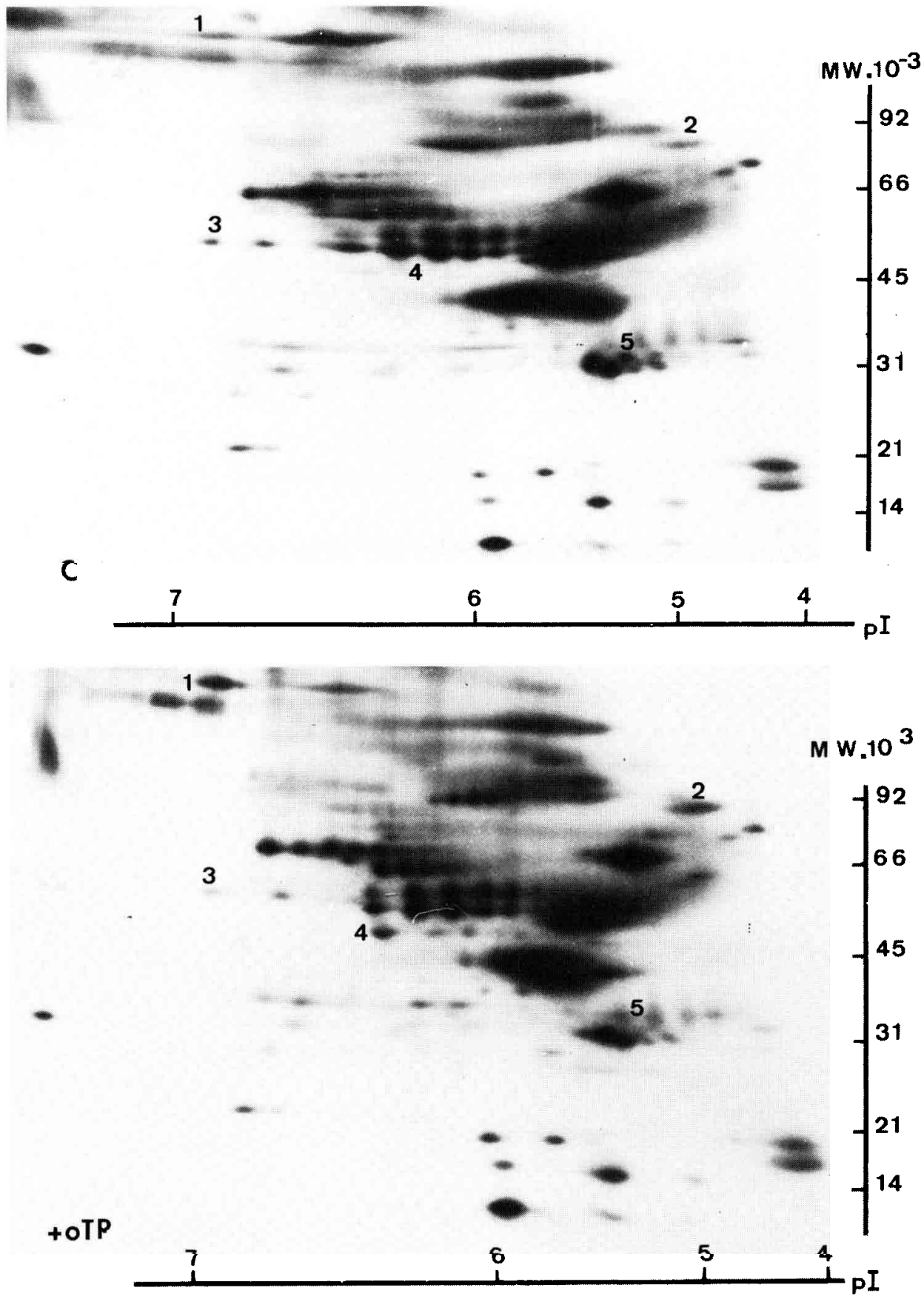

FIG. 9. - Autoradiograph of 2D-PAGE profiles of proteins secreted by uterine epithelial cells from Day 12 non pregnant ewe cultured with BSA as control (C) or with oTPB. Number represent proteins which are controlled by oTPB. 

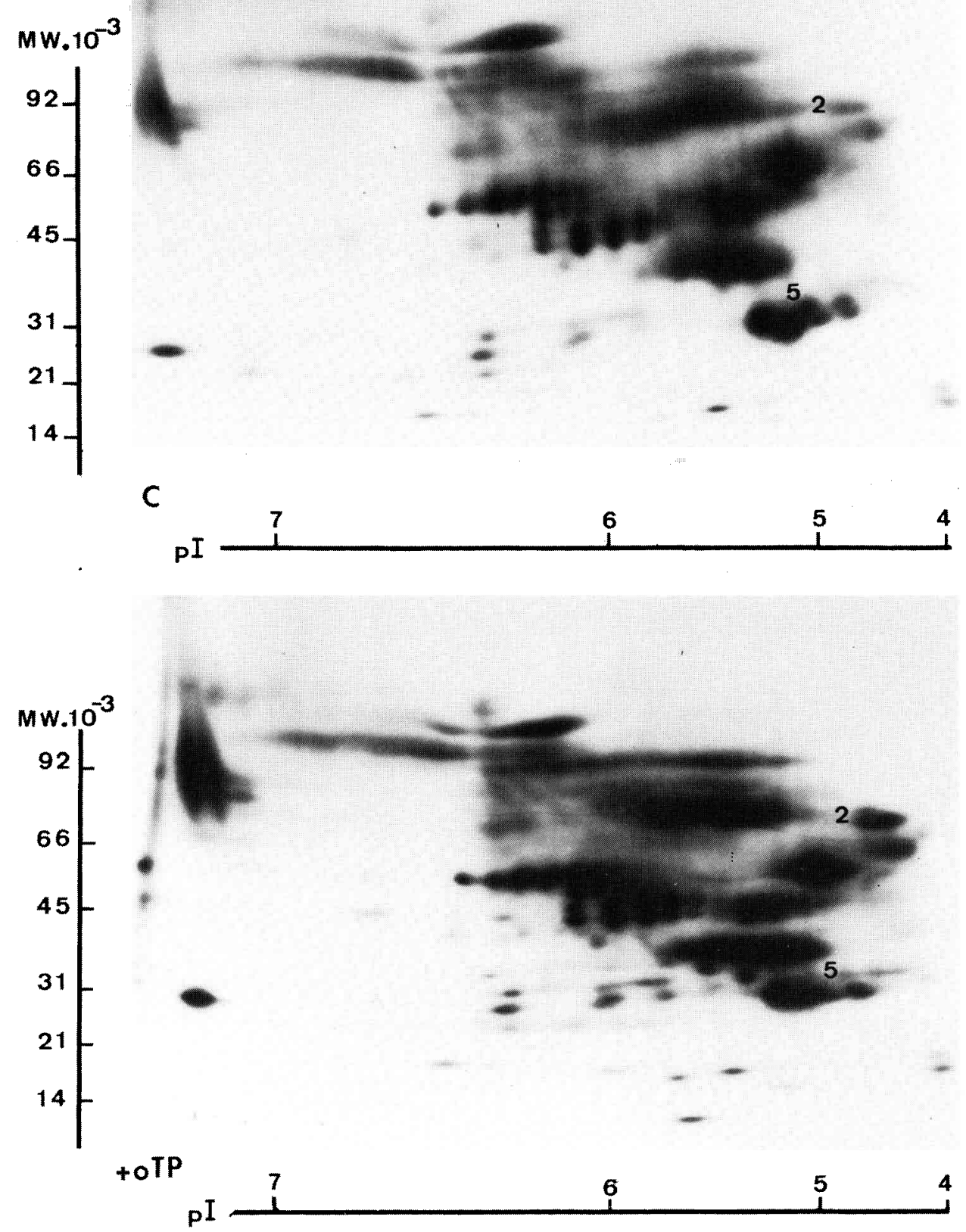

FIG. 10. - Autoradiograph of 2D-PAGE profiles of proteins secreted by a mixed population of fibroblast and epithelial cel/s from Day 12 non pregnant ewe cultured with BSA as contro/ (C) or with oTP. Numbers correspond to those in figure 9. 


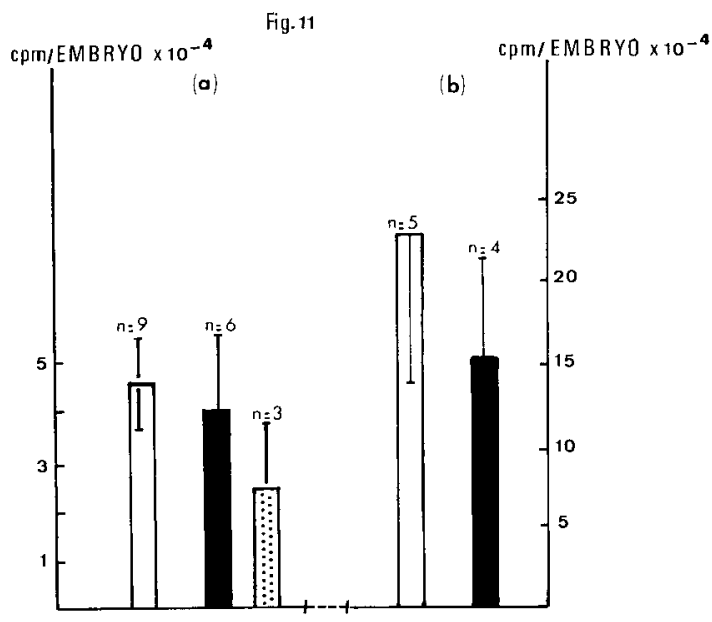

FIG. 11. - Incorporation of ${ }^{3} \mathrm{H}$-thymidine into DNA by Day $11-12$ blastocysts ( $1 \mathrm{~mm}$ in diameter) (a) and $3 \mathrm{~mm}$ in diameter (b) during co-culture for $24 \mathrm{~h}$ with uterine epithelial cells (solid bars) or a mixed population of fibroblast and epithelial cells (dotted bar). Control blastocysts (open bars) were cultured with BSA. Results are expressed as mean \pm SE.

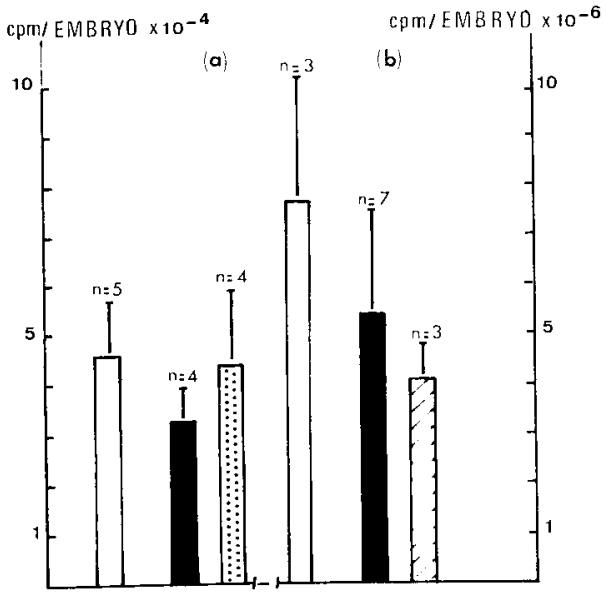

FIG. 12. - Incorporation of ${ }^{35} \mathrm{~S}$-met into cellular proteins by a) Day 11 blastocyst (1 $\mathrm{mm}$ in diameter) and b) Day 12 blastocysts ( $2 \mathrm{~cm}$ in lenght) after coculture $(24 \mathrm{~h})$ with epithelial cel/s (solid bars) or a mixed population of fibroblasts and epithelial cells (dotted bar). Incorporation was realized into a mixture of dialysed medium from cell cultures and renewed MEM medium ( $v / v)$ or in the dialysed medium from the coculture period (hatched bar). Results are expressed as mean $\pm \mathrm{SE}$.

inhibitory factors in endometrial secretion is not understood. It may be assumed that the uterine secretory products could activate the growth of the embryo but 
also limit it. In in vitro conditions, the equilibrium between activator and limiting factors is displaced towards the limiting ones. Examples of limiting factors of trophoblastic growth is shown in the pig with plasmin inhibitor (see above). In humans, it has also been reported that IGF-binding protein secreted by the endometrium could control the proliferation of trophoblast into decidual tissue (Bell, 1988).

In vitro cultures of embryos in the presence of fractionnated media from endometrial cell culture could help to characterize the factors which are involved in this regulation.

\section{Conclusion.}

In summary, the data reviewed here do not clearly demonstrate the presence of "pregnancy specific » uterine proteins during the early stages of gestation in domestic mammals. The uterine environment is merely conditioned by the hormonal status of the dam. The fact that an embryo develops when transferred into a recipient uterus shows that the host-medium is « immediately » sufficient to support its development, at least before implantation. The only prerequisite is a narrow synchrony between the stage of development of the embryo and the recipient endometrium. In such conditions a "dialogue» between these two partners can be established. One of the results of these interactions would be a local modification of the uterine environment under the control of the embryo. However, these subtle changes are quite difficult to detect by analysis of the total secretory proteins of the endometrium. Although various hypotheses have been put forward (corpus luteum maintenance, growth of the embryo, immunosuppressive effect) for uterine proteins during the early stages of pregnancy, their functions remain obscure. Answers to these questions will come from the characterization of the different components of the uterine secretions.

$27^{e}$ Réunion de la Société française pour l'Etude de la Fertilité. Paris, 29, 30 sept., $1^{\text {er }}$ oct 1988

Acknowledgements. - We would like to thank Dr. J.-E. Fléchon and Ms Bernadette Fléchon for help in techniques of microscopy; M. R. Scandolo for the photographic works; Ms. Emilie Ouvrard and Ms Marie-Elisabeth Marmillod for typing the manuscript and Ms. Annick Bouroche for English translation.

Résumé. Interactions embryo-utérines pendant les premiers stades de la gestation chez les animaux domestiques.

Dans la première partie de cet article, les connaissances actuelles sur les protéines du début de la gestation (implantation) sont présentées chez diverses espèces de mammifères domestiques. Dans la seconde partie, l'analyse biochimique des interactions embryoutérines chez la brebis est plus particulièrement développée. Parmi les mammifères domestiques, la lapine et la truie représentent les espèces chez lesquelles les produits de sécrétions utérines ont été particulièrement bien étudiés. Chez la lapine, l'utéroglobine (ou blastokinine) est maintenant bien connue. Cette protéine est un facteur majeur des 
sécrétions endométriales de la lapine sous l'influence de la progestérone. Toutefois, si sa structure et la régulation de sa synthèse sont bien connues, son rôle au cours de la gestation est encore à déterminer. La seule propriété bien établie de l'utéroglobine est de lier la progestérone. Bien qu'un rôle embryotrophique, qui lui valut d'abord d'être appelée blastokine, lui ait été attribué, il n'a pas été démontré par la suite. Chez la truie, l'utéroferrine est sans doute une des protéines utérines les mieux connues. Cette protéine basique est sécrétée par l'endomètre de truie en phase lutéale et a un rôle de transporteur de fer vers le conceptus. Dans cette espèce, d'autres protéines impliquées dans les phénomènes nutritifs embryonnaires ont également été décrites (protéine liant l'acide rétinoïque). Chez les autres espèces domestiques, la brebis ou la vache, la présence de protéines utérines spécifiques n'est pas clairement établie. Une des raisons de ce manque d'information est sans doute liée aux faibles quantités de protéines sécrétées dans la lumière utérine. Bien que des protéines utérines spécifiques de gestation aient été décrites, aucune d'entre elles n'a été clairement identifiée. Afin de pallier ce problème, différentes études in vitro ont été entreprises pour mettre en évidence d'éventuelles protéines endométriales spécifiques d'un stade de gestation donnée. A ce jour, aucune protéine n'a pu être clairement caractérisée. Chez la brebis ou la vache, des variations très fines des sécrétions utérines pourraient se produire sous l'influence de l'embryon et passeraient inaperçues par l'analyse des protéines totales de l'endomètre.

Nous avons mis au point un modèle in vitro de culture de cellules épithéliales utérines ovines en présence de blastocystes ou de ses sécrétions protéiques. Les cellules épithéliales utérines sont obtenues après digestion enzymatique de l'endomètre selon le protocole décrit à la figure 1 . Nous obtenons ainsi des populations de cellules épithéliales dépourvues de fibroblastes (figs. 3,4). De plus, nous avons étudié l'effet, dans ce système, d'une des protéines majeures sécrétées par l'embryon du $9^{\mathrm{e}}$ au $22^{\mathrm{e}}$ jour de gestation. Cette protéine, appelée trophoblastine ou oTP (ovine trophoblastic protein) et impliquée dans le maintien de l'activité du corps jaune, a été récemment isolée. Les modifications de la synthèse protéique des cellules endométriales ont été analysées par autoradiographie des électrophorèses mono et bidimensionnelles des protéines après incorporation d'un acide aminé radioactif. Les résultats indiquent que le blastocyste (fig. 5), l'ensemble des protéines qu'il sécrète ou l'oTP seule (fig. 7) ont une action inhibitrice sur la synthèse protéique des cellules endométriales. Cependant, les blastocystes n'entraînent pas de modifications qualitatives des profils électrophorétiques (fig. 6). Par contre, l'addition d'oTP aux cellules endométriales modifie le profil électrophorétique des protéines sécrétées : la synthèse de trois protéines augmente $\left(\mathrm{PM}=150 \cdot 10^{3} ; 74 \cdot 10^{3} ; 50 \cdot 10^{3}\right.$ et $\mathrm{pl}=7-7,2 ; 5,2-5,4 ; 6,4$ respectivement) et deux protéines ont une synthèse réduite $\left(P M=57.10^{3} ; 35.10^{3}\right.$ et $\mathrm{pl}=6,7-7 ; 5,3$ respectivement) (figs. 9, 10).

De plus, l'effet des sécrétions utérines sur la multiplication cellulaire du blastocyste a été étudié par la mesure de l'incorporation de ${ }^{3} \mathrm{H}$ thymidine dans le DNA. Après co-culture avec les cellules endométriales, nous observons un ralentissement de la synthèse du DNA (fig. 11) et des protéines embryonnaires (fig. 12).

En conclusion, si la présence de protéines utérines spécifiques semble bien établie dans quelques espèces (porc, lapin), il n'en est pas de même pour les autres animaux domestiques. Bien que des modifications locales de synthèses protéiques puissent être induites par l'embryon ou ses sécrétions, la nature et le rôle des protéines affectées restent à déterminer. L'effet inhibiteur des sécrétions utérines sur le développement embryonnaire in vitro que nous avons observé est quelque peu paradoxal. En effet, on attribue généralement à l'environnement utérin un rôle embryotrophique. Il serait plus juste de considérer cet environnement comme «permissif». Le milieu utérin maintiendrait l'embryon et le préparerait à l'implantation, mais en même temps contrôlerait son développement. Les techniques de co-culture d'embryons sur monocouches cellulaires utérines ou en présence de milieux de culture conditionnés par ces cellules permettraient de caractériser les facteurs impliqués dans cette régulation. 


\section{Références}

ADAMS K. L., BAZER F. W., ROBERTS R. M., 1981. Progesterone-induced secretion of a retinol-binding protein in the pig uterus. J. Reprod. Fert., 62, 39-47.

AITKEN R. J., 1981. Aspects of delayed implantation in the roe deer (Capreolus capreo/us). $J$. Reprod. Fert., Suppl. 29, 83-95.

ALLEN R. L., WRIGHT R. W., Jr., 1984. In vitro development of porcine embryos in co-culture with endometrial cell monolayers or culture supernatants. J. anim. Sci., 59, 1657-1661.

BARTOL F. F., ROBERTS R. M., BAZER F. W., THATCHER W. W., 1985. Characterization of proteins produced in vitro by bovine endometrial explants. Biol. Reprod., 33, 745-759.

BASHA S. M. M., BAZER F. W., ROBERTS R. M., 1980. Effect of the conceptus on quantitative and qualitative aspects of uterine secretions in pigs. J. Reprod. Fert., 60, 41-48.

BASU S., KINDAHL H., 1987. Prostaglandin biosynthesis and its regulation in the bovine endometrium : a comparison between non pregnant and pregnant status. Theriogenology, 28, 175-193.

BAZER F. W., ROBERTS R. M., SHARP III D. C., THATCHER W. C., 1981. Uterine proteins synthetized during the progestative period and pregnancy. In BOURY-HEYLER C., MAULEON P., ROCHET Y., Utérus et fécondité, 17-32. Masson, Paris.

BEATO M., 1977. Physico-chemical characterization of uteroglobin and its interaction with progesterone. In JOHNSON M. H., Development in mammals, Vol. 2, 173-198. NorthHolland, Amsterdam.

BEIER H. M., 1976. Uteroglobin and related biochemical changes in the reproductive tract during early pregnancy in the rabbit. J. Reprod. Fert., Suppl. 25, 53-69.

BELL S., 1988. Endometrial IGF-binding protein : a paracrine role in controlling endometrial or trophoblast growth? Res. Reprod., 20, 3.

BULLOCK D. W., 1977. In vitro translation of messenger RNA for a uteroglobin-like protein from rabbit lung. Biol. Reprod., 17, 104-107.

CHANDRA T., WOO S. L. C., BULLOCK D. W., 1980. Cloning of the rabbit uteroglobin structural gene. Biochem. Biophys. Res. Commun., 95, 197-204.

CHARPIGNY G., REINAUD P., HUET J. C., GUILLOMOT M., CHARLIER M., PERNOLLET J. C., MARTAL J., 1988. High homology between a trophoblastic protein (trophoblastin) isolated from ovine embryo and $\alpha$-interferons. FEBS Letters, 228, 12-16.

CHEN T. T., BAZER F. W., GESHARDT B. M., ROBERTS R. M., 1975. Uterine secretion in mammals : synthesis and placental transport of a purple acid phosphatase in pig. Biol. Reprod., 13, 304-313.

DANIEL J. C. Jr., 1976. Blastokinin and analogous proteins. J. Reprod. Fert., Suppl. 25, 71-83.

DIXON S. N., GIBBONS R. A., 1979. Proteins in the uterine secretions of the cow. J. Reprod. Fert. 56, 119-127.

DUNBAR B. S., DANIEL J. C., 1979. High molecular weight components of rabbit uterine fluids. Biol. Reprod., 21, 723-733.

EYESTONE W. H., FRENCH L. R., 1981. Uterine specific antigens in the ewe. Theriogenology, 16. 359-371.

FAZLEABAS A. T., BAZER F. W., ROBERTS R. M., 1982. Purification and properties of a progesterone-induced plasmin/trypsin inhibitor from uterine secretions of pigs and its immunochemical localization in the pregnant uterus. J. biol. Chem., 257, 6886-6897.

FAZLEABAS A. T., GEISERT R. D., BAZER F. W., ROBERTS R. M., 1983. The relationship between the release of plasminogen activator and estrogen by blastocysts and secretion of plasmin inhibitor by uterine endometrium in the pregnant pig. Biol. Reprod., 29, 225-238.

FINDLAY J. K., ACKLAND N., BURTON R. D., DAVIS A. J., MAULEWALKER F. M., WALTERS D. E., HEAP R. B., 1981. Protein, prostaglandin and steroid synthesis in caruncular and intercaruncular endometrium of sheep before implantation. J. Reprod. Fert., 62, 361-377.

FINDLAY J. K., CLARKE I. J., SWANEY J., NOELENE C., DOUGHTON B., 1982. Oestrogen receptors and protein synthesis in caruncular and intercaruncular endometrium of sheep before implantation. J. Reprod. Fert., 64, 329-339. 
FLINT A. P. F., 1981. A unifying hypothesis for the control of blastocyst growth based on observations of the pig. J. Reprod. Fert., suppl. 29, 215-227.

FUKUI Y., ONO H., 1988. In vitro development to blastocyst of in vitro matured and fertilized bovine embryos. Vet. Rec., 122, 282.

FRIDLANDSKY F., MILGROM E., 1976. Interaction of uteroglobin with progesterone, 5-pregnane-3,20-dione and estrogens. Endocrinology, 99. 1244-1251.

GANDOLFI F., MOOR R. M., 1987. Stimulation of early embryonic development in the sheep by co-culture with oviduct epithelial cells. J. Reprod. Fert., 81, 23-28.

GODKIN J. D., BAZER F. W., ROBERTS R. M., 1984. Ovine trophoblast protein 1, an early secreted blastocyst protein, binds specifically to uterine endometrium and affect protein synthesis. Endocrinology, 114, 120-130.

GROSS T. S., THATCHER W. W., HANSEN P. J., JOHNSON J. W., HELMER S. D., 1988 . Presence of an intracellular endometrial inhibitor of prostaglandin synthesis during early pregnancy in the cow. Prostaglandins, 35, 359-378.

GUILLOMOT M., CHARLIER M., REINAUD P., DEBOST B., MARTAL J., 1987 . Effet du trophoblaste sur les sécrétions protéiques endométriales in vitro chez la brebis. In CLAUSER H., SCHOLLER R., Les récepteurs hormonaux dans /a reproduction, 179-182, Masson, Paris.

IMAKAWA K., ANTHONY R. V., KAZEMI M., MAROTTI K. R., POLITES H. G., ROBERTS R. M., 1987. Interferon-like sequence of ovine trophoblast protein secreted by embryonic trophectoderm. Nature, 330, 377-379.

KIRCHNER C., 1972. Immune histologic studies on the synthesis of a uterine specific protein in the rabbit and its passage through the blastocyst coverings. Fertil. Steril., 23, 131-136.

KIRCHNER C., 1980. Non-uteroglobin proteins in the rabbit. In BEATO M., Steroid induced uterine proteins, 69-86. Elsevier, North-Holland.

KRISHNAN R., DANIEL J. C. Jr., 1967. "Blastokinin" inducer and regulator of blastocyst development in the rabbit uterus. Science, N.Y, 158, 490-492.

KUZAN F. B., WRIGHT R. W., Jr., 1982. Observations on the development of bovine morulae on various cellular and non-cellular substrata. J. anim. Sci., 59, 1657-1661.

LASTER D. B., 1977. A pregnancy-specific protein in the bovine uterus. Biol. Reprod., 16, 682-690.

MARQUANT-LE GUIENNE B., GERARD M., THIBAULT C., 1988. Possibilité de développement in vitro de l'œuf de vache jusqu'au stade de blastocyste éclos sur tapis de cellules tubaires et/ou de cellules utérines. $27^{\mathrm{e}}$ Réunion de la Soc. franç. pour l'Etude de la Fertilité, Paris, 29 , 30 sept., $1^{\text {er }}$ oct. 1988.

MARTAL J., CHÊNE N., CHARLIER M., CHARPIGNY G., CAMOUS S., GUILLOMOT M., REINAUD P., BERTIN J., HUMBLOT P., 1988. Proteins trophoblastiques. Reprod. Nutr. Dévelop., 28. $1655-1672$

MARTAL J., LACROIX M. C., LOUDES C., SAUNIER M., WINTENBERGER-TORRES S., 1979. Trophoblastin, an antiluteolytic protein present in early pregnancy in sheep. J. Reprod. Fert., 56. 63-73.

MARTIN L., 1984. On the source of uterine « luminal fluid » proteins in the mouse. J. Reprod. Fert., 71, 73-80.

MÉNEZZ Y., 1981. Sécrétions utérines associées à la phase périovulatoire et à la vie libre des blastocystes. In BOURY-HEYLER C., MAULEON P., ROCHET Y., Utérus et fécondité, 3-16. Masson, Paris.

MIELE L., CORDELLA-MIELE E., MUKHERJEE A. B., 1987. Uteroglobin : structure, molecular biology and new perspectives on its function as a phospholipase $A 2$ inhibitor. Endocr. Rev., 8, 474-488.

MILLIGAN S. R., MARTIN L., 1984. The resistance of the mouse uterine lumen to flushing and possible contamination of samples by plasma and interstitial fluid. J. Reprod. Fert., 71, $81-87$.

MOORE N. W., SHELTON J. N., 1964. Egg transfer in sheep. Effect of degree of synchronization between donor and recipient, age of egg and site of transfer on survival of transferred eggs. J. Reprod. Fert., 7, 145-152.

MORNON J. P., FRIDLANSKY F., BALLY R., MILGROM E., 1980. X-ray cristallographic analysis of a progesterone-binding protein. The C2221 crystal form of oxidized uteroglobin at $2.2 \mathrm{~A}$ resolution. J. mol. Biol., 137, 415-429. 
MULLINS D. E., BAZER F. W., ROBERTS R. M., 1980. Secretion of a progesterone-induced inhibitor of plasminogen activator by the porcine uterus. Cell, 20, 865-872.

NOSKE J. G., FEIGELSON M., 1976. Immunological evidence of uteroglobin (blastokinin) in the male reproductive tract in non-reproductive ductal tissue and their secretions. Biol. Reprod., 15, 704-713.

PONSTINGL H., DIETO A., BEATO M., 1978. Amino-acid sequence of progesterone-induced uteroglobin. Biochemistry, 17, 3908-3912.

POPE W. F., FIRST N. L., 1985. Factors affecting the survival of pig embryos. Theriogenology, 23. 91-105.

POPP R. A., FORESMAN K. R., WISE L. D., DANIEL J. C., 1978. Amino-acid sequence of a progesterone binding protein. Proc. nat. Acad. Sci. USA, 75, 5516-5519.

PSYCHOYOS A., CASIMIRI V., 1981. Uterine blastotoxic factors. In GLASSER R., BULLOCK D. W., Cellular and molecular aspects of implantation, 327-334. Plenum Press, New York.

RICE C., ACKLAND N., HEAP R. B., 1981. Blastocyst-endometrial interactions and protein synthesis during pre-implantation development in the pig studied in vitro. Placenta, 2. 129-142.

ROBERTS G. P., PARKER J.. M., 1974. Macromolecular components of the luminal fluid from the bovine uterus. J. Reprod. Fert., 40, $291-303$.

ROBERTS G. P., PARKER J. M., SYMONDS H. W., 1976. Macromolecular components of genital tract fluids from the sheep. J. Reprod. Fert., 48, 99-107.

ROBERTS R. M., BAZER F. W., BALDWIN N., POLLARD W. E., 1976. Induction of lysozyme and leucine aminopeptidase activities in the uterine flushings of pigs by progesterone. Arch. Biochem. Biophys., 177, 499-507.

ROBERTS R. M., BAZER F. W., 1988. The functions of uterine secretions. J. Reprod. Fert., 82 , 875-892.

ROBERTS R. M., RAUB T. J., BAZER F. W., 1986. Role of uteroferrin in transplacental iron transport in the pig. Fed. Proc. Fed. Am. Soc. exp. Biol., 45, 2513-2518.

ROWSON L. E. A., MOOR R. M., 1966. Embryo transfer in the sheep: the significance of synchronizing oestrus in the donor and recipient animal. $J$. Reprod. Fert., 11, 207-212.

ROWSON L. E. A., LAWSON R. A. S., MOOR R. M., BAKER A. A., 1972. Egg transfer in the cow synchronisation requirements. J. Reprod. Fert., 28, 427-431.

SALAMONSEN L. A., DOUGHTON B. W., FINDLAY J. K., 1986. The effects of the preimplantation blastocyst in vivo and in vitro on protein synthesis and secretion by cultured epithelial cells from sheep endometrium. Endocrinology, 119, 622-628.

SALAMONSEN L. A., STUCHBERY S. J., O'GRADY C. M., GODKIN J. D., FINDLAY J. K., 1988. Interferon-mimics effects of ovine trophoblast protein 1 on prostaglandin and protein secretion by ovine endometrial cells in vitro. J. Endocr., 117, R1-R4.

SAVOURET J. F., LOOSFELT H., ATGER M., MILGROM E., 1980. Differential hormonal control of a mRNA in two tissues. Uteroglobin mRNA in the lung and the endometrium. J. biol. Chem., 255, 4131-4136.

SCHLOSNAGLE D. G., BAZER F. W., TSIBRIS J. C. M., ROBERTS R. M., 1974. An iron containing phosphatase induced by progesterone in the uterine fluids of pigs. J. biol. Chem., 249, 7574-7579.

SCHLOSNAGLE D. C., SANDER E. G., BAZER F. W., ROBERTS R. M., 1976. Requirement of an essential thiol group and ferric iron for the activity of the progesterone-induced porcine uterine purple phosphatase. J. biol. Chem., 251, 4680-4685.

SERGERSON E. C., 1988. Suppression of interleukin-2-mediated T-lymphocyte blastogenesis by ovine uterine luminal protein. Biol. Reprod., 38, 256-263.

SIMMEN R. C. M., LIU X. H., BREW K., ROBERTS R. M., 1987. Isolation and characterization of cDNA clones encoding porcine uteroferrin. Endocrinology, 120, suppl. 133, abstr. 450.

STAPLES L. D., LAWSON R. A. S., FINDLAY J. K., 1978. The occurrence of an antigen associated with pregnancy in the ewe. Biol. Reprod., 19, 1076-1082.

STEWART H. J., Mc CANN S. H. E., BARKER P. J., LEE K. E., LAMMING G. E., FLINT A. P. F., 1987. Interferon sequence homology and receptor binding activity of ovine trophoblast antiluteolytic protein. J. Endocr., 115, R13-R15. 
SURANI M. A. H., 1975. Hormonal regulations of proteins in the uterine secretion of ovariectomized rats and the implications for implantation and embryonic diapause. J. Reprod. Fert., 43, $411-417$

VALLET J. L., BAZER F. W., ROBERTS R. M., 1987. The effect of ovine trophoblastic protein-one on endometrial protein secretion and cyclic nucleotides. Biol. Reprod., 37, 1307-1316.

WALES R. G., 1973. The uterus of the ewe. Chemical analysis of uterine fluid collected by cannulation. Aust. J. Biol. Sci., 26, 947-959.

WATHES D. C., 1980. Protein synthesis by bovine chorion and uterine endometrium during the period of implantation. J. Reprod. Fert., 60, 323-330.

WEITLAUF H. M., 1976. Effect of uterine flushing on RNA synthesis by « implanting " and « delayed implanting » mouse blastocysts in vitro. Biol. Reprod., 14, 566-571.

WEITLAUF H. M., 1978. Factors in mouse uterine fluid that inhibit the incorporation of $\mathrm{H}$-uridine by blastocyst in vitro. J. Reprod. Fert., 52, $321-325$.

WILMUT I., SALES D. I., ASWORTH G. J., 1985. The influence of variation in embryo stage and maternal hormone profiles on embryo survival in farm animals. Theriogenology, 23, 107-119.

ZAVY M. T., SHARP D. C., BAZER F. W., FAZLEABAS A., SESSIONS F., ROBERTS R. M., 1982. Identification of stage-specific and hormonally-induced polypeptides in the uterine protein secretions of the mare during the oestrous cycle and pregnancy. J. Reprod. Fert., 64. 199-207. 